\begin{tabular}{|c|c|c|c|}
\hline \multirow{2}{*}{ 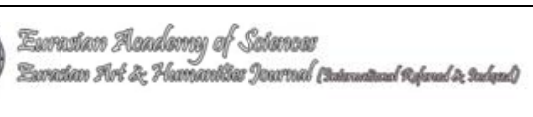 } & \multicolumn{3}{|c|}{$\begin{array}{l}\text { Eurasian Academy of Sciences } \\
\text { Eurasian Art \& Humanities Journal }\end{array}$} \\
\hline & 2015 & Volume:1 & S: $1-11$ \\
\hline \multicolumn{4}{|c|}{$\begin{array}{l}\text { Published Online April } 2015 \text { (http://arthum.eurasianacademy.org) } \\
\text { http://dx.doi.org/10.17740/eas.art.2015-V1-01 }\end{array}$} \\
\hline
\end{tabular}

\title{
POLITICAL AND ECONOMIC RELATIONS OF ANCIENT GREEK TEMPLES
}

\author{
Yrd. Doç. Dr. Ahmet Deniz *, Dr. Ayhan Yardimciel**, Özlem TOY*** \\ Kafkas Üniversitesi*, Kafkas Üniversitesi**, Sıdkı Koçman Üniversitesi *** \\ E-mail: ahmetdenizz@hotmail.com*,ayhanyardimciel@gmail.com**
}

Copyright (C) 2015 Ahmet Deniz, Ayhan Yardimciel, Özlem TOY. This is an open access article distributed under the Eurasian Academy of Sciences License, which permits unrestricted use, distribution, and reproduction in any medium, provided the original work is properly cited.

\begin{abstract}
Religion and belief concepts accompanied human in the adventure that they lived throughout history. The religion phenomenon within the culture, which was transferred to future generations by developing and accumulating, is quite important. Humankind built their first religious buildings in coordination with the need to shelter. These sanctuaries, which were generally defined as temples until the emergence of divine religions, were turned into central economic Powers with the compensations granted. Their economic powers and oracles activities they applied based on prophecy enabled their political effects to emerge at the same time together with religion. This system was seen to settle especially in Western Anatolia. In the background of struggles between Persian-Lydia and Persian-Greek, effects of temples on politics attract the attention. However, Ancient Greek temples never transformed into institutions above politics. Temples were rather purported as an advisory council.
\end{abstract}

Keywords: Temple, Prophecy, Western Anatolia, Economy, Politics

JEL-Clasification: N00, B00

\section{Antik Yunan Tapınaklarının Siyasi ve Ekonomik İlişkileri}

ÖZET: Din ve inanç kavramı; insanın tarih boyunca yaşadığı serüvende ona eşlik etmiştir. Geliştirip, biriktirerek gelecek nesillere devrettiği kültür içinde din olgusu oldukça önemlidir. İnsanoğlu barınma ihtiyacı ile eş güdümlü olarak ilk dini yapılarını da inşa etmiştir. Semavi dinlerin ortaya çıkışına kadar genel anlamda tapınak olarak tanımlanan bu mabetler, yapılan bağışlarla merkezi bir ekonomik güce dönüşmüşlerdir. Ekonomik güçleri ve uyguladıkları kehanet odaklı bilicilik faaliyetleri onların aynı zamanda din ile birlikte siyasi etkilerinin de ortaya çıkmasına olanak sağlamıştır. Özellikle Batı Anadolu'da bu sistemin hayata geçtiği görülmektedir. Pers-Lidya ile Pers-Yunan mücadelelerinin arka planında tapınakların siyasete olan etkileri göze çarpmaktadır. Ancak, Antik Yunan tapınakları hiçbir zannan siyaset üstü bir kuruma dönüşmemiştir. Tapınaklar daha ziyade danışma meclisi görünümünde olmuşlardır.

Anahtar Kelimeler: Tapınak, Kehanet, Batı Anadolu, Ekonomi, Siyaset 


\section{GíRiş}

İnsana dair her türlü somut ve soyut birikim kültürü meydana getirmektedir. Din ve inanç da kültürün içinde var olan olgulardandır ve en az insanlık tarihi kadar eskidir. İnsan ile ilgilenen bilim dalı olan Antropoloji'nin sosyo/kültürel antropoloji ve din antropolojisi gibi alt dalları da bulunmaktadır. Din olgusunu destekleyen en önemli etken, inanca bağlı inanmak eylemidir. İnanmak bir şeylerden emin olup ona güvenmek ile ilgilidir. $\mathrm{Bu}$ bir düşünsel eylemdir. Düşünmek, akıl kullanılarak yapılan bir eylemdir (Temren, 1998: 301-311). O halde kültürün oluşmasında aklın birinci elden etkisi bulunmaktadır. Üst Paleolitik Çağ’dan itibaren Avrupa kıtasında bulunan dönemin yerleşme yerleri olan mağaralarda Ana Tanrıça'nın örnekleri tespit edilmiştir. Magna Mater olarak da bilinen bu kült Frigler zamanında Kibele olarak karşımıza çıkmaktadır (Oral, 2014: 154).

Anadolu'da gerçekleştirilen arkeolojik kazılarda yerleşmeler içinde ayrı mimari özellikler taşıyan yapılar tespit edilmiştir. Daha sonra bu yapıların aslında ilk tapınaklar olduğu anlaşılmıştır. Batman yakınlarındaki Hallan Çemi ile Çayönü’nün erken tabakaları ve Urfa'da bulunan Göbeklitepe de bu tür yapıların ilk örnekleri bulunmaktadır. Genellikle yuvarlak planlı olan yapılar taşla örülmüş yüksek duvarlara sahiptirler. Sal taşları ile döşenen tabanlı bu yapıların en gelişmiş örneği Göbeklitepe'dir. Buradaki tapınak içinde bulunan boyu üç-dört metre civarındaki dikilitaşlar üzerine işlenmiş insan ve hayvan betimlemeleri ilk totem inançlar olarak da kabul edilmektedir (Özdoğan, 2011: 60-61). Göbeklitepe'de bulunan tapınak avcı-toplayıcı insanların müthiş bir işbirliği ile ortaya çıkmıştır. Bununla birlikte aynı tapınak yeri yerleşik yaşama geçiş içinde ipuçları barındırmaktadır (Schmidt, 2011: 65).

Güney Mezopotamya'da tapınaklar, ellerinde tuttukları araziler, hayvan sürüleri ve insan gücü ile sadece dini bir merkez olmamışlardır. Bu tapınaklar aynı zamanda siyasetin ve ekonominin nabzını da tutmaktaydılar. Lügal isimli ilk Sümer kralları Patesi ve Ensi gibi dini unvanlarda kullanmışlardır (Demirel, 2013: 11).

Anadolu coğrafyasında tarımsal faaliyetlerin tapınakların ve sarayların tekelinde olmasından dolayı gelişimi kısıtlanmıştır. Neolitik çağda toplulukların yaşamlarını devam etmeleri için tarım ürünleri yetiştirilmeleri gerekmiştir. Tarım arazileri de tapınaklara ve saraya bağlı olduğu için, buralara vergi verilmesi gerekmiştir. Devlet kendisine ait gördüğü arazileri kira yöntemi ile halka verirdi. Bir süre sonra, Mülkiyet hakkı kazanan toprak sahibi bu seferde vergi ödemek zorunda kalmıştır. Ama burada önemli olan mülkiyet hakkının tanınmış olmasıdır (Eğilmez, 2005: 35).

\section{DİNİ KARAKTERLİ DEVLETLERIN İLK ÖRNEKLERİ}

Şu an için en popüler tartışmalardan biri din-devlet ve ekonominin nasıl ve hangi zamanda bir araya geldiğidir. Bu konu ile ilgili farklı yaklaşımlar bulunmaktadır. Ancak temel olarak iki görüş öne çıkmaktadır. Birincisi Mezopotamya kökenli ilk devletlerin ortaya çıkışının sulamaya bağlandığı görüştür. Bu görüşe göre; Dicle ve Fırat nehirlerine lbağlı yapılan tarım, bu nehirlerin akış düzeni/düzensizliği ve benzeri birçok konuda yapılan iş bölümü bu toplumları siyasi bir otorite altında birleştirme yoluna gitmiştir. Diğer bir görüş devlet olgusunun ruhani kaygılarla ortaya çıktığına yöneliktir. Devlet olgusu bu bölge toplumlarının dinsel inançlarının somut dünyaya yansımış halidir (Ateş ve Ünal, 2004: 22- 23). Ancak bilinen gerçek Sumer insanlarının bu bölgede ilk monarşiyi hayata geçirmeleridir. Zigguratlar sosyal hayatın tüm yönleriyle yaşandığı merkezler olmuştur. Başlarında ise "Rahip Kral" anlamına gelen Patesi ünvanlı yöneticiler bulunmaktaydı (Milosavljevıç, 2007: 4).

Hititlerde de din kavramı çok ayrıcalıklı görülmüş ve toplumu şekillendiren kavramların en etkilileri arasında yer edinmiştir. Dini düşüncelerin toplumun her alanında yer edinmiş olduğu 
Hititlerde, toprağın tamamı saraya veya tapınaklara bağlı olmuştur. Fakat tüm bunlara rağmen özel mülkiyet hakkının tanındığı yasalar da mevcut olmuştur. Hitit yasalarında 168. madde halka özel mülkiyet hakkı da vermiştir (Ertem, 1972: 84). Bu bağlamda toprağı işletme hakk1 kral, tapınak ve halk arasında olmuştur.

Tapınaklara verilen araziler dışında, halka verilen arazilerde de asıl amaç halkın üretimi sürekli sağlayarak iktisadi hayatın herhangi bir aksaklığa uğramaması düşünülmüştür. Kral tarafından toprağın işletilmesi halka verilirken, halk istediğinde toprağını arttırma imkânına da sahip olmuştur. Genellikle arazinin satın alınması, veraset yoluyla devredilmesi veya bağış olarak bırakılması yoluyla halk arazisini genişletebilmiştir. $\mathrm{Bu}$ da yine yasaların verdiği haklar çerçevesinde yapılabilmiştir (Klengel, 1986: 25-26).

Hititlerde de araziler ve onların işletilmesi, evrenin ve insanlığın sahibi Fırtına Tanrısına ait olduğu düşünülmüştür. Fakat tanrının arazileri işleme hakkını Labarna'ya bıraktığı yani toprağın işlenmesi için kralın gönderildiği ve kralın istediğini uygulayabileceği düşüncesi hâkim olmuştur (Güterbock, 1997: 229). Böyle bir durum krallıkla yönetilen bir devletin ayakta durması için gerekli olmasıyla beraber, aynı zamanda eski Anadolu topluluklarının hepsinde de devletin devamı için gerekli görülmüsştür. Karmaşık toplulukları içinde barındıran devletlerde ekonomik güç iyi olduğu sürece bir arada yaşama duygusu perçinleşir. Bundan dolayı tapınakların gelirlerini arttırarak, devlet içinde yaşayan etkin kişilerin bağlılığını sağlamlaştırmak istemişlerdir (Yakar, 2000: 48). Gelirlerin birçoğunun tapınaklara bağlanmasıyla beraber güçlenen Hitit ekonomisi, yöneticilerin ülkenin her kentinde kurup yönettikleri tapınaklar aracılığıyla güçlerini korumaya çalıştıkları görülmüsştür (Beckman, 1989: 98-108). Hitit kraliçesi Pudu-Hepa, Tanrıça Lelwani’ye yapmış olduğu adak metinleriyle bilinmektedir. Buna göre, Kraliçe, eşi III. Hattuşili'nin sağlığı ve hayatı için tanrıçanın tapınağına yıllık, aylık ve günlük adaklar adayarak hediyeler vereceğini taahhüt etmektedir (Demirel, 2013: 95).

$\mathrm{Bu}$ noktada toplumların inanç ve eylem şekilleri, tarihsel süreç içerisinde diş etkilere ya da değişen toplumsal ve ekonomik koşullara uyum sağlayarak bir takım değişiklikler göstererek oluşan bir birikimin sonucudur (Macqeueen, 2013: 122).

\section{ANTIK YUNAN'DA DİN-DEVLET-EKONOMI ILIŞKİSI}

Zaman içinde gelişen, kutsal sayılıp adlandırılan din olgusu devletlerin siyasi işleyişlerinde etkileri görülmektedir. Özellikle küçük aile ocaklarından büyük tapınaklara doğru ilerleyen dini yapılar da ekonomik olarak da siyasi olarak da güçlenmiştir. Birçok din incelendiğinde görülmektedir ki tanrılar ya da kutsal sayılan varlıklarla iletişim kuran çeşitli dini görevliler vardır. Genellikle rahipler olarak karşımıza çıkan bu görevliler, bizzat tanrılar tarafından korunduklarına ve özel olduklarına inanılsa da devlet yönetimine hâkim ayrı bir sınıf oluşturamamışlardır (Freeman, 2005: 224).

Rahiplik kurumu devlet tarafından kontrol altında tutulmuş ve yetersiz kişilerin bu kurumu ele geçirmesine izin verilmemiştir. Bu nedenle rahiplik genellikle soyuna miras kalan bir sınıf olmuştur. Çünkü bu görevliler tapınak törenlerini bizzat denetleyen, kurban törenlerini usulüne göre gerçekleştiren kişilerdir. Rahipler bu törenler sırasında sadece tanrıları memnun etmekle kalmaz aynı zamanda onlarla iletişime geçerler. Tanrılar işaretlerini yorumlamak bu rahiplerin en önemli meziyetlerindendir (Bettany, 2005: 468).

Rahiplere toplumun bu denli saygı duymasının anlayabilmek için Antik Yunan toplumun dini algısı görebilmek faydalı olacaktır. Onlar tanrılarını inanç dünyaların da hem kutsal bir yere koymuş hem de insani bir takım özellikler yükleyerek, tapınmayı sürdürmüşlerdir. Tanrılar tıpkı insanlar gibi yiyeceklere, içeceklere ihtiyaç duyarlardı. Bu ihtiyaçlar yeme-içmeyle 
sınırlı düşünmek yeterli değildir. Tanrıların, insanlar gibi tutkuları vardır, güzel ve kötü işler yapabilirler onlarının insanlardan ayıran en büyük fark ölümsüz olmalarıdır (Akurgal, 2005: 319). Bu ölümsüz tanrıları her yerde bulmak mümkündür ve onlar her şeyi bilirler. Çok güçlü olan bu tanrılar doğa olaylarından sorumlu oldukları gibi bireylerin eylemlerine de yön verebilirler (Estin-Laporte, 2012: 2).

Antik Yunanlılar bir takım hırsları ve tutkuları olan tanrıları ya da tanrıçalarını öfkelendirmekten, onların gazabına uğramaktan çekinmektedir. Bu nedenle Tanrılarına ibadet etmek, sunu sunmak, onları onurlandırmak dışında aldıkları kararları Tanrıların onaylayıponaylamadığını bilmek oldukça önemlidir. Çünkü bireysel suçların cezasını tüm sitenin ödeyebileceği antik yazarlar tarafından anlatılmaktadır. Hesiodos, İşler ve Günler adlı eserinde detaylı bilgiler bulunmaktadır. Burada bir kişinin işlediği suçtan dolayı herkesin eziyet çekebileceği vurgulanmaktadır (Hesiodos, 2012: 24).

Tanrıları memnun etmek ve onların gazabından korunmak oldukça önemlidir. Tanrılarda insanoğlunu bu noktada yalnız bırakmamışlardır. Tanrılar varlıklarını bir takım işaretler ile belli etmektedir (Estin-Laporte, 2012: 2). Ancak bu işaretleri doğru yorumlamak oldukça önemlidir. Tanrısal işaretleri yorumlama konusunda kehanet olgusu devreye girmektedir. İnsanı bu işaretleri yorumlamaya iten en temel duygu meraktır. Gelecekteki hayatın belirsizliği, korkular, bireysel arzular ve hırslar insanların geleceği bilme dürtüsünü arttırmıştır. İnsanoğlu da gelecekten haber verme, olacakları önceden öngörmek için kehanete ihtiyaç duymuştur (Öğüt ve Öğüt, 2000: 22). Kehanet, tanrısal ilham ya da sezgi yoluyla bir takım işaretlerden yola çıkarak bilinmezden haber verme, gelecek hakkında ön bilide bulunma sanatidir.

Kehanette bulunan yani tanrısal söz söyleyen, gelecekten haber veren kişiler kâhinlerdir. Kâhinlik bir takım işaretleri yorumlayarak, çevredeki nesneleri gözlemleyerek ya da doğrudan tanrısal güçlerle iletişim kurarak geleceği söyleme sanatıdır. Kâhinlik sıradan bir uğraş değil, alanında uzmanlık gerektiren bir meslek grubudur. Bu kişiler işlerinde uzman genellikle soyunu güçlü bir kâhine dayandıran kimselerdir. Kâhinlik mesleğini ailleden miras alarak devam ettirenler olduğu gibi güçlü bir kâhin tarafından yetiştirilip evlatlık olan kâhinlerin de olduğu bilinmektedir (Burkert, 2012: 59).

Kâhinlerin tanrısal sözleri danışanları ilettiği bilicilik ocakları Yunancada manteion ya da khresterion olarak karşımıza çıkmaktadır (Howatson, 2014: 142). Bu bilicilik ocakları devletlerin kaderin de oldukça önemli olduğunu Pers- Yunan savaşları sırasında görmekteyiz.

İnsanlar kehanete ihtiyaç duyduklarında veyahut teşekkür amaçlı olarak tapınaklara para ödemekteydiler. Bu uygulama doğrultusunda Apollon adına toplanan sikkelere göz kulak olmak için iki rahip görev yapardı (Estin-Laporte, 2012: 72-73). Kehanet merkezlerinin üç tanesi çok önemlidir. Bunlardan ilki Yunanistan'da bulunan Delphoi'dir. Diğer iki önemli kehanet merkezi ise Batı Anadolu'da bulunan Didyma (Didim) ve Klaros'tur. Delphoi ve Didyma' da Hellen vatandaşı olmayanların müracaatları kabul edilmezken, Klaros "Ben dünya vatandaşlığına açığı" sloganı ile kölelerin bile başvuru yapacağı bir merkez haline dönüşür ve bundan dolayı M.S. 1 ve 2. yüzyıllarda dünyanın en zengin ve en önemli kehanet merkezi haline gelir (Şahin, 2009: 10-11). Bir kısmı Batı Anadolu'da bulunan Antik Yunan kehanet merkezlerinin Sümer tapınaklarından ayrımı devlet yönetiminde söz sahibi olmamalarıdır. Daha ziyade danışma kurulu gibi görev yapmaktadırlar. Delos övgüsünde tanrıça Leto’ya hitaben şu dizeleri ilgi çekicidir (Erhat, 1996: 45); 
Senin olursa okçu tanrı Apollon'un tapınă̆g,

Görürsün, insanlar nasıl yüzlük kurbanlarla buraya gelir,

Nasıl toplanır insanlar burada ve dumanlar tüter

Yanan yağlı etlerden, hiç durmadan;

Madem senin topră̆ında hiç bereket yok,

Sende beslenir semirirsin başka elden.

Tanrıça ağzından dile getirilmiş olan bu dizeler Delphoi tapınağının temel felsefesi haline getirilmiş ve Delphoi kısa sürede tüm bilicilik merkezlerini geride bırakacak bir refah seviyesine ulaşmıştır

Batı Anadolu ve Yunanistan'1 kapsayan Antik Yunan Çağı'nda tapınak/kehanet ocakları ulaşmış oldukları zenginlik sonucu olarak birer cazibe merkezi haline gelmişlerdir. Krallar da zaman zaman bu kehanet merkezlerine başvuru yaparak siyasi hareketlerini ve planlarını bu tapınaklardan gelen cevaplara göre düzenlemişlerdir. Tapınakların kehanetlerine göre siyasi değişiklikler, Frigya-Lidya-Pers ve Helenizm zamanında doruk noktasına ulaşmıştır. Lidya Krallığı'nda meydana gelen taht değişikliğinden Lidya'nın Perslilerce işgaline kadar hemen hemen tüm aşamalarda bu din merkezlerinin etkileri görülmüştür. Ancak yukarda belirtildiği üzere bu dini merkezler Mezopotamya'da bulunanlarının aksine danışma ve tavsiye merkezi görünümündedirler. Ancak buradan çıkan söylemler siyasi erkin başında bulunan krallar tarafından sıkça ciddiye alınmıştır. Lidya kralı Kandaules zamanında Gyges isimli bir asker kralın en çok güvendiği adamlarından biriydi (Cartledge, 2002: 37).

Kral Kandaules karısının güzelliği ile sürekli övünür ve bunu her ortamda sıkça dile getirmekten çekinmezdi. Gyges'in kendisine inanmadığını düşünerek ve zorla karısını Gyges'e göstermeye karar veren Kandaules, Gyges'in önceden yatak odasına gizler ve karısı soyunduğu sırada asker Gyges onu seyreder. Ancak, Kandaules'in eşi, Gyges tarafından izlendiğini görür ve ertesi gün yanına çağırtıp ya Kandaules'i öldürerek Lidya tahtına ve kendisine sahip olmasına veyahut kendi canından olacağını belirtir. Bunun üzerine Gyges yine aynı yatak odasında yapılan bir plan sonucu kralı Kandaules’i öldürür. İşte bu aşamada halk arasında çıkan karışıklığı gidermek ve olayları yatıştırmak için Delphoi tapınağına başvuru yapılır. Delphoi tapınağın Heraklesoğulları sülalesi yerine Gyges’in mensubu olduğu Mermnad sülalesinin başa geçmesini onaylar. Ancak Delphoi kehanet merkezi şu kehaneti verir (Herodotos, 1991: I. 13).

\section{“Heraklesoğulları öçlerini alacaklar ve Gyges 'in dördüncü kuşak torununu vuracaklar”.}

Hakikaten Gyges'in dördüncü kuşaktan torunu olan Lidya kralı Kroïsos yaklaşan Pers tehlikesi karşısında danışacağı tapınağı başvuru yapmak için bile emin olmak istediğinden bir oyun hazırlar. Bu göre Kroisos'un birçok adamı birçok farklı yerde bulunan kehanet merkezlerine gidecekler ve yüzüncü gün sonunda Kroisos'un ne yaptığını soracaklardı. Birçok tapınak içinde doğru cevabı Delphoi Tapınağı bilir. Delphoi Tapınağı'ndan şu kehanet gelir (Herodotos, 1991: I. 47-48); 
Kumsaldaki kum tanelerini sayarım, denizi ölçerim.

Dilsizin sözünü anlarım; konuşmayanı dinlerim

Bir koku geliyor burnuma; kaplumbağa

Tunçta pişirilmiş, kuzu ile beraber ve sarılmış

Kalın bir deriye; tunçtan bir örtü var üstünde,

Ve tunç bir yatak serilmiş altına.

Gerçekten de Kral Kroisos ne yapacağını düşünürken, bir kaplumbağa ile bir kuzuyu dilim dilim kesip tunç kapaklı tutamaklı bir tunç tencerede pişirmeyi akıl etmişti. Bu kehanetin gerçekleşmesinden sonra Kroisos'un Delphoi kehanet merkezine itimadı en üst noktaya ulaşmıştır. Sonraki başvurusunda Kroisos, Perslilerle savaşıp savaşmaması hususunda ve savaşırsa bir dost ülkeden yardım alıp almaması hususlarını sordurmuştur. Delphoi kehanet merkezi şu kehaneti göndermiştir (Herodotos, 1991: I. 53);

"Eğer Perslerle savaşa girerse büyük bir imparatorluğu devirecektir; Yunanlların en güçlülerine başvurup dostluklarını sağlaması gerekiyor”.

Keyfi iyice yerine gelen Kroisos bu kez saltanat süresi ile ilgili olarak Delphoi kehanet merkezine başvuruda bulunur ve kendisine şu kehanet gönderilir (Herodotos, 1991: I. 55);

\section{Günün birinde katır Med'lere kral olacak}

O zaman, ey yumuşak ayaklı Lydia'lı kaç,

Çakıllı Hermos boyunca, tabanları yağla,

Utanma, yüzün kızarmasın kaçtığın için.

Kroisos hem savaş ve hem de saltanat süresi ilgili kehanetleri yanlış yorumlamıştır. Pers imparatorluğunu yıkacağından emin olan Kroisos bir katırın da tahta geçmesinin imkânsız olduğunu düşünerek savaş hazırlıklarına başlamıştır. Tabi bu kehanetlerin karşılığında Delphoi Tapınağı altına doyarken, Lidyalılar ise Delphoi'de ücretsiz konaklama ve vatandaşlık hakkı elde etme gibi imtiyazların sahibi olmuşlardır. Ancak bilindiği üzere meydana gelen savaşta Lidyalılar yıkılmış ve Pers İmparatorluğu tüm Anadolu'ya egemen olmuşlardır. Esir düşen Kroisos zincirlerini Lidyalılara vererek Delphoi Tapınağı'na göndermiş ve büyük bir imparatorluğu yıkacaktır sözünü anımsatarak neden kehanetin gerçekleşmediğini sormalarını istemiştir. Lidyalı görevliler Delphoi tapınağına gider ve Kroisos'un sorusunu kâhinlere sorarlar. Kâhinler görevlilere, Kroisos'un esasen dördüncü kuşaktan dedesi Gyges'in günahını çektiğini belirtirler. Buna göre Gyges tahtı hakkı olmadığı halde ve yasal olmayan yollarla ele geçirmişti. O zaman da bu olay Delphoi tapınağına iletilmişti. Tapınak kâhinleri her ne kadar tahtı Gyges'e bırakmış olsalar bile Heraklesoğulları'nın öçlerini alacaklarını ve Gyges'in dördüncü kuşaktan torununu vuracaklarını söylemişlerdi. İşte dördüncü kuşaktan torun şimdi Persler tarafindan tahttan indirilen Kroisos'tu. Ayrıca kâhinler Kroisos'un Perslerle savaşa girdiğinde sonuç ne olacak sorusunun cevabını kendine göre yorumladığını tekrar bir ulak gönderip kimin yeneceğini sormas1 gerektiğini de belirtmişlerdir (Herodotos, 1991: I. 90-91). 
M.Ö. 7. yüzyılda sikkenin icadı ile birlikte, Atina'daki Athena Tapınağı, Efes’teki Artemis Tapınağı ve Delphoi Apollon Tapınağı ekonomik açıdan bir sıçrama göstermişlerdir. Tapınaklar elde ettikleri bağışlar yoluyla zaten bir sermaye birikimine kavuşmuşlardı. Buna ek olarak tanrının kutsal alanı olduğu için birçok kişi de değerli eşyalarını ve paralarını bu tapınaklara emanet birakmaktaydılar. Tapınaklar bununla birlikte farklı nedenlerle de sikkelerin toplandığı merkezler haline gelmiştir. Bu durum tapınakların sikke konusunda uzmanlaşmasına neden olmuştur. Farklı ayar ve değerdeki sikkelerin yarattığı karmaşıklığın farkına varan Delphoi'nin uyanık rahipleri kısa bir süre sonra kendi sikkelerini basmaya başladılar. Amphiktyon sikkeleri kısa sürede Attika'nın ortak sikkesi haline geldi. M.Ö. 5-4. yüzyıllarda Athena Tapınağı'nın bir banka gibi borç verme emanet tutma işlemlerini yürüttüğü bilinmektedir (Ildız, 2013: 95).

Thukydides'in eseri Peloponnessos Savaşları'nda Delphoi Kehanet Merkezi'nin bahsi şu şekilde geçmektedir. Atina ve Spartalıların müttefikleri ile beraber imzaladıkları anlaşmaya göre Delphoi tapınağ 1 eskiden olduğu gibi yönetilecek. Bu anlaşma beş yıl geçerli olacak ve denizde karada ve iç kısımlarda iyi bir şekilde denetlenecekti (Thukydides, 2010: 18).

Kısa süre içinde Batı Anadolu topraklarına egemen olan Persler burada bulunan Didyama (Didim) Tapınağı'nı da yıkmışlardır. Pers işgali sırasında Miletos'la birlikte Apollon Tapınağı da tahrip edildi ve Apollon'un bronz heykeli Pers başkentine götürüldü. Herodotos, Miletosluların erkeklerinin uzun saçlı Persliler elinde can verdiklerin kadın ve çocukların köle yapıldığını ve Didyma tapınağının da yıkıldığını belirtir (Herodotos, 1991: VI. 1).

Anadolu'da bulunan Didyma'daki Apollon Tapınağı'nda yapılan arkeolojik kazılar, kehanet başvurusu yapan insanlar, bu insanların geldikleri bölgeler ve yaptıkları bağışlarla ilgili birçok bilgi ortaya çıkarmıştır. Bu tapınağa Anadolu ve Yunanistan'dan birçok kişinin gelerek kehanet talebinde bulunduğu anlaşılmaktadır. Bu belgelerden birinde SeleukosNikator ve Antiokhos'un Didyma'ya adak olarak bin koyun ve on iki boğa gönderdikleri anlaşılmaktadır. Bununla birlikte altın ve gümüş üçayaklar ve çeşitli hediyelerde diğer bağışlar arasındadır (Parlak, 2012: 42-43).

Batı Anadolu'da bulunan diğer önemli tapınaklardan biri de Telmessos kehanet merkezidir. Herodot, Lidya kralı Kroisos'un Pers savaşından önce bu merkeze de başvuru yaptığını belirtir (Herodotos, 1991: I. 175-183). Şehirle ilgili başka bir kehanet ise şöyledir; İ̀kender, Halikarnassos'u istila ettiği dönemde, gün ortasında uyuya kalmıştır ve o uyurken bir kırlangıcın onun yatağının etrafında daireler çizerek uçtuğu rivayet edilir. Kırlangıç olağan dışı sesler çıkarak İskender'in uyanmasına kadar bu ritüeline devam etmiştir. Bunun üzerine Telmessos'lu kâhinlere danışan İskender arkadaşlarından birisinin kendisine tuzak kurduğunu öğrenir (Bean, 1999: 40).

Telmessos ile ilgili en ilginç kehanetlerden birisi Phrygia kralı Midas'ın doğum hikâyesi ile ilgili olandır. Buna göre; Phrygia'lı fakir bir köylü olan Gordios, tarlasında çalıştığı bir zamanda bir kartal sürekli olarak bu köylünün başında uçar, bunun kutsal bir işaret olduğunu hisseden Gordios, Telmessos kâhinlerine başvuru yapar. Telmessos'un bïr köyünde bir kıza bu durumu anlatan Gordios, kızdan geri dönerek aynı yerde Zeus'a bir kurban adak etmesi tavsiyesini alır. Gordios kızdan kendisiyle beraber gelerek sunuda yardımcı olmasını rica eder. Bunun üzerine Gordios'la birlikte kurban ritüelini gerçekleştiren bu kız sonrasında Gordios ile evlenirler ve Midas bu evlilikten dünyaya gelir. Kral Midas, bir efsaneye göre Tanrı Apollon ile arkadaştır. Eşekkulaklı Midas olarak bilinen bu kral, bir yarışma sırasında hakemlik yapamayınca Apollon tarafindan cezalandırılır (Can, 2011: 82-83). Kentle ilgili diğer bir kehanet Sardes krallarından Meles zamanında gerçekleşmiştir. 
Kral Meles, Sardes'in akropol kısmının güvenliği için araştırma yaparken Telmessos kâhinlerine haber gönderir, bunun üzerine kâhinler kralın aslanını eğer akropolün etrafını bir tam defa dönerse orayı kimse alamaz, ancak kral aslanını her taraftan dolaștırdığı halde akropolün bir dik yamacından çıkarmamıştı buradan bir saldırı gelmeyeceğini öngörmüştü. Gerçekten bir anlamda kâhinlerin kehanetleri gerçekleşmişti çünkü aslanın çıkarılmadığ bu dik yamaçtan uzun zaman sonra Pers askerleri çıkarak şehir işgal ettiler (Herodotos, 1991: I. 84).

Telmessos kehanet merkezi Pers-Lydia mücadelesi zamanında bir kehanetle daha bilinmektedir. Buna göre, Lydia-Pers arasındaki ilk çarpışmadan sonra Kroisos, geri çekilip bir kış boyunca hazırlık yapıp yeniden saldırmayı düşündüğü Sardes'e geldiğinde, şehrin girişinin yılanlar, sürüngenlerle sarıldığını görmüş̧ü ve o sırada otlamakta olan atlar otlamayı bırakarak bu sürüngenleri avlamaya başlamışlardı. Bunun üzerine Kroisos bunun tanrılardan bir işaret olduğunu düşünerek Telmessos kâhinlerine başvurur. Telmessos kâhinlerinin kehaneti şu şekilde iletilir kendisine (Herodotos, 1991: I. 78);

"Kroisos, üzerine yabancl dil konuşan bir ulusun yürümesini beklesin; bunlar ülkeye yayılacak, yerlileri boyunduruk altına alacaklar; zira yılanlar toprağın oğludur, at ise savaşçı ve göçebe bir hayvandır".

Ancak habercilerin bu cevabı Sardes'e ulaşmadan şehir Perslilerce on dört günlük bir kuşatmadan sonra alınır. Lidya devletinin yıkılmasından sonra bölgenin kontrolü Perslerin eline geçmiştir. Persler çeşitli seferlerinde Likya'nın askeri gücündün de faydalanmıştır (Efendioğlu, 2010: 6-7).

Antik Yunan Kültürü’nün devamında ve Hıristiyanlık öncesi Roma Kültürü'nde de tapınak merkezli siyasi ve ekonomik ilişkilerin varlığ göze çarpmaktadır. Roma ile Kartacalılar arasında yapılan II. Kartaca Savaşı sırasında da Romalıların savaşın akıbeti açısından tapınak kâhinlerine başvuru yaptıkları bilinmektedir. Roma ileri gelenleri, savaşta Roma'nın galip gelmesi için Sibilla bilicilerine başvuru yapmışlar ve karşılığında Kybele'nin kutsal siyah meteor taşının Roma'ya getirilmesi halinde zaferin Roma'nın olacağı kehanetini almışlardır. Bundan dolayı Anadolu'da bulunan bahsi geçen taş Roma'ya getirilir. Kybele bağlantılı bu hadise sonrasında Kybele (Magna Mater) Kültü'nün Roma'ya getirilişi, Megalensia Bayramı olarak 4-10 Nisan tarihleri arasında her yıl kutlanmıştır. Bayramın ilk günü olan 4 Nisan'da tanrıçanın rahiplerinden oluşan bir tören alayı, tahtına oturmuş halde Kybele heykelini insanların taşıdı̆̆ 1 bir arabayla Roma'nın caddelerinde dolaştırarak halkıtan para toplarlardı (Parlak, 2012: 40).

\section{SONUÇ}

İnsanoğlu yeryüzünde var olduğu ilk andan günümüze dek büyük bir gelişim süreci göstermiştir. İnsanlık tarihini etkileyen en önemli konulardan bir tanesi inançtır. İnanmak, insan için bir ihtiyaçtır. Bireyler bu ihtiyacı karşılamak için çeşitli inanç şekilleri geliştirmişlerdir. İşte bu inanç şekilleri din olarak karşımıza çıkmaktadır. Farklı coğrafyalarda birbirinden farklı toplumlar tarafından inanılan ve bu inanç sistemini yaşam biçimi haline getiren bireyler din olgusunun çağlar boyu kendisiyle birlikte var olmasını sağlamıştır. $\mathrm{Bu}$ nedenle birbirinden farklı inanç sistemleri oluşmuş farklı isimler almıştır. Dinler tarihinin eski dönemleri incelendiğinde insanoğlunun inançlarıyla sadece kendi ruh dünyalarını ve yaşam biçimlerini şekillendirmekle kalmadığını aynı zamanda yaşadığı toplumun, devlet mekanizmasının işleyiş biçimini de şekillendirdiğini görmekteyiz.

Özellikle pagan kültürünün yaygın olduğu dönemlerde Mezopotamya, Anadolu ve Yunanistan'da farklı özellikler gösterse de, din, devlet ve ekonominin belli oranlarda 
birbirleriyle ilişkili oldukları görülmektedir. Mezopotamya'da din adamları siyasi ve sosyal hayatında belirleyicisi konumunda iken, Batı Anadolu ve Yunanistan'dakiler danışma rolündedir. Batı Anadolu ve Yunanistan coğrafyasında bulunan tapınaklar/kehanet merkezleri ile siyasi otorite arasında genellikle altın sunağına karşılık siyasi tavsiye ve fikirler bağlamında alış veriş olmuştur. Bu fikirler genellikle idareciler tarafından ciddiye alınarak reel hayatta uygulanmıştır.

Tüm bu noktalar göz önüne alındığında inanç insanların yaşamlarını şekillendiren en önemli unsurlardan bir tanesidir. Bireylerin yaşamı düzenleyen, toplumsal ilişkilerine şekil veren ve yönetim olgusunda kendini hissettiren güçlerden bir tanesi bireylerin inanç dünyasıdır. Özellikle antik dünyada gerek günlük yaşamda gerek devlet yönetiminde etkin rol alan yöneticiler aldıkları kararlarda tanrıları memnun etmeyi ve onarlın gazabından korunmaya özen göstermiş. Tanrılarla insan ilişkilerini düzenleyen din adamları yine tanrıların düşüncelerini insanlara iletmeye çalışan kâhinler toplumda büyük sayg1 görürken, tapınaklarda ibadet etmek, tanrılara sunu sunmak tüm toplumca uyulması gereken bir zorunluluk haline gelmiştir. Zamanla güçlenen tapınaklar ve biriken hazineleri ekonomik ve siyasi anlamda güçlenmelerine bu sayede sadece dini alanda etkin olmakla kalmayıp, farklı alanlarda da etkinlik kazanmalarına olanak sağlamıştır. 


\section{REFERENCES}

- AKURGAL, Ekrem (2005), Anadolu'nun Kültür Tarihi, Tübitak Yayınları, Ankara.

- ATEŞ, Hamza ve Soner Ünal (2004), "Devletin Doğduğu Yer: Antik Çağ Ortadoğusu'nda İdari Hayat”, Bilgi Dergisi, S.8, s.21-44.

- BEAN, E. George (1998), Eskiçağ'da Güney Kıyılar, Çev: İnci Delemen-Sedef Çokay, Arion Basım Yayın, İstanbul.

- BECKMAN, Gary (1989) "The Religion of the Hittites", The Biblical Archaeologist, Vol. 52, No. 2/3, pp.98-108.

- BETTANY, G.T. (2005), Dünya Dinleri Ansiklopedisi, Çev: Ahmet Aydoğan, Say Yayınları, İstanbul.

- BURKERT, Walter (2012), Yunan Kültüründe Yakındoğu Etkileri, Çev: Mehmet F. Yavuz, İthaki Yayınevi, İstanbul.

- CAN, Şefik (2011), Klasik Yunan Mitolojisi, Ötüken Neşriyat, İstanbul.

- CARTLEDGE, Paul (2002), The Cambridge Illustrated History of Ancient Greece, Cambridge University Press New York.

- DEMİRL, Serkan (2013), Hitit İnanç Sistemi ve Ekonomi İlişkisi, (Ankara Üniversitesi Sosyal Bilimler Enstitüsü Eskiçağ Tarihi Doktora Tezi), Ankara.

- EFENDİOĞLU, Tuba (2010), Hellenistik ve Roma Çağlarında Likya'da Yerel Tanrı ve Tanrıçalar, Arkeoloji ve Sanat Yayınları, İstanbul.

- EĞİLMEZ, Mahfi (2005), Hitit Ekonomisi, Türk Eskiçağ Bilimleri Enstitüsü, Ege Yayınları, İstanbul.

- ERHAT, Azra (1996), Mitoloji Sözlüğü, Remzi Kitabevi Yayınları, İstanbul.

- ERTEM, Hayri (1972), "Çivi Yazılı Metinlere Göre Hititlerde Tarla Tarımı," VII. TTK Kongresi Bildirileri, Cilt 2 (25-29 Eylül 1970), Ankara.

- ESTIN, Colette ve Helene Laporte (2012), Yunan ve Roma Mitolojisi, Çev: Musa Eran, Tübitak Popüler Bilim Kitapları, Ankara.

- FREEMAN, Charles (2005), Mısır-Yunan ve Roma: Antik Akdeniz Uygarlıkları, Çev. Suat Ang1, Dost Kitapevi, Ankara.

- GÜTERBOCK, Hans Gustav (1997), "Authorityand Law in the Hittite Kingdom", Perspectives on Hittite Civilization: Selected Wiritings of Hans G. Güterbock, Assynological Studies No: 26, Editör: Thomas A. Holland and Thomas G. Urban, The Oriental İnstitute of the Universty of Chicago, İllinois Üniversty, Chicago.

- HERODOTOS (1991), Herodot Tarihi, Çev: Müntekim Ökmen, Remzi Kitabevi, İstanbul.

- HESIODOS (2012), İşler ve Günler-Tanrıların Doğası, Çev: Furkan Akderin, Say Yayınları, İstanbul.

- HOWATSON, M. C. (2014), Oxford Antikçağ Sözlüğü, Çev: Tarık Ersöz, Kitap Yayınevi, İstanbul.

- ILDIZ, Erkan (2013), Eskiçağ'da Bankacılık ve Bankerlik, Türkiye Bankalar Birliği Yayını, Yayın No: 297, G.M. Matbaacılık ve Ticaret A.Ş., İstanbul.

- KLENGEL, Horst (1986), "The Economy of the Hittite Household”, Oikumene, V 5, pp. 23-31.

- MACQUEEN, J. G. (2013), Hititler ve Hitit Çağında Anadolu, Çev: Esra Davutoğlu, Arkadaş Yayınevi, III. Baskı, Ankara.

- MílOSAVLJEVIÇ, Vıktor (2007), Sumer and Akkad: Societyand Legal Change; Acculturationand Diffusion of Law, (Unıversty of Belgrade School of Law), Belgrade.

- ORAL, Ebru (2014), “Anadolu'da Ana Tanrıça Kültü”, Akademik Sosyal Araştırmalar Dergisi, Y11 2, sayı 8, Aralık, s.154-164. 
- ÖĞÜT, Elvan ve Gündüz Öğüt (2000), Kehanetler ve Kahinler, Ege Meta Yayınları, 2. Bask1, İzmir.

- ÖZDOĞAN, Mehmet (2011), "Çanak Çömleksiz Neolitik Çă̆", Tarih Öncesinden Demir Çağı'na Anadolu'nun Arkeoloji Atlası, İstanbul, s.56-63.

- PARLAK, Serkan (2012), Antik Yunan Anadolu Kültleri ve Kült Merkezleri, (Kültür ve Turizm Bakanlığı, Güzel Sanatlar Genel Müdürlüğü, Uzmanlık Tezi), Ankara.

- SCHMIDT, Klaus (2011), "Göbeklitepe”, Tarih Öncesinden Demir Çağı'na Anadolu'nun Arkeoloji Atlası, İstanbul, s.64-65.

- ŞAHIN, Nuran (2009), "Kehanet ve Klaros", Osmanlı Bankası Arşiv ve Araştırma Merkezi, 25 Mart, s. 1-11, http://www.obarsiv.com/pdf/nuran_sahin.pdf (ET: 01.02.2015).

- TEMREN, Belkıs (1998), "Din Antropolojisi Açısından İnanç ve Din Olgusuna İlişkin Bir Değerlendirme", Ankara Üniversitesi Dil ve Tarih-Coğrafya Fakültesi Dergisi, Cilt 38, Say1 1-2, Ankara, s. 301-311.

- THUKYDİDES (2010), Peloponnessos Savaşları, Çev: Furkan Akderin, Belge Yayınları, İstanbul.

- YAKAR, Jak (2000), Anadolu'nun Etnoarkeolojisi, Homer Kitabevi ve Yayınları; İstanbul. 